\title{
Analysis of Interlayer Idle Time as a Temperature Control Technique in Additive Manufacturing of Thick Walls by Means of CMT and CMT Pulse Welding Processes
}

\author{
Régis Henrique Gonçalves e Silva ${ }^{1}$ (D), Pedro Correa Jaeger Rocha ${ }^{1}$ (D), Max Baranenko Rodrigues ${ }^{2}$ (D), Milton Pereira² (D), Daniel Galeazzi ${ }^{1}$ (D) \\ 1 Universidade Federal de Santa Catarina - UFSC, Instituto de Soldagem e Mecatrônica LABSOLDA, Florianópolis, SC, Brasil. \\ 2 Universidade Federal de Santa Catarina - UFSC, Laboratório de Mecânico de Precisão - LMP Laser, Florianópolis, SC, Brasil.
}

How to cite: Silva RHG, Rocha PCJ, Rodrigues MB, Pereira M, Galeazzi D. Analysis of interlayer idle time as a temperature control technique in additive manufacturing of thick walls by means of CMT and CMT pulse welding processes. Soldagem \& Inspeção. 2020;25:e2501. https://doi.org/10.1590/0104-9224/SI25.01

\begin{abstract}
Inserted in the scenario of innovations and technological trends of Industry 4.0, this work aims to obtain detailed knowledge on the influence of idle time between layers as thermal control technique for the Wire Arc Additive Manufacturing (WAAM) with two GMAW process variants of high controllability (CMT and CMT Pulse). The problem focuses on the deposition of thick walls, seeking to emulate the challenges of manufacturing big parts with medium geometric complexity, such as propellers and screws, which usually have sections of this thickness. Although works in the area of additive manufacturing point out the use of idle time as a feature to stabilize the thermal gradient, detailed information about the thermal behavior ends up being omitted. Both processes variants used presented high metallic transference stability and low thermal input when compared to the conventional GMAW, being positive differentials for WAAM. In the tests, walls with eight layers were built with ER309LSi steel in which the interlayer idle time varied from 0 to $300 \mathrm{~s}$. It can be concluded that both processes are WAAM compliant, and that although the CMT Pulse has a higher energy input, the temperature control by idle time was able to control the thermal accumulation in the part for both processes.
\end{abstract}

Key-words: 3D print; WAAM; GMA welding based additive manufacturing; MIG/MAG based additive manufacturing; Advanced manufacturing; Thermography.

\section{Análise do Tempo de Espera entre Camadas como Técnica de Controle Térmico na Manufatura Aditiva de Paredes Espessas pelos Processos de Soldagem CMT e CMT Pulsado}

\begin{abstract}
Resumo: Inserido no cenário de inovações e tendências tecnológicas da Industria 4.0, esse trabalho visa obter conhecimento detalhado da influência do intervalo de tempo entre a deposição de camadas como técnica de controle térmico do processo Wire Arc Additive Manufacturing (WAAM) com duas variantes do processo GMAW de alta controlabilidade (CMT e CMT Pulse). A problemática foca na deposição de paredes espessas, buscando emular os desafios da fabricação de peças grande e com média complexidade geométrica, como hélices e fusos, as quais usualmente apresentam seç̧ões com esta característica. Embora trabalhos na área de manufatura aditiva apontem o uso do tempo entre camadas como uma ferramenta de estabilização do gradiente térmico, informações detalhadas sobre o comportamento térmico acabam sendo omitidas. Além disso, por questões de produtividade, maior entendimento sobre os fenômenos térmicos envolvidos são necessários, como subsídio para racionalização do ciclo de trabalho (redução de tempos de espera). As duas versões do processo utilizadas possuem alta estabilidade na transferência metálica e alta controlabilidade do aporte térmico se comparado ao GMAW convencional, sendo diferenciais positivos para o WAAM. Os experimentos envolveram a construção de paredes com oito camadas de aço ER309LSi, nas quais variou-se o tempo entre camadas de 0 a $300 \mathrm{~s}$. Pode-se concluir que o ambos os processos são aptos ao WAAM, e, que embora o CMT Pulse tenha aporte energético superior, o controle de temperatura por tempo de espera entre camadas foi capaz de controlar o acúmulo térmico na peça para ambos os processos.
\end{abstract}

Palavras-chave: Impressão 3D; WAAM; Manufatura aditiva via Soldagem à Arco e Arame; MIG/MAG; Manufatura avançada; Termografia. 


\section{Introduction}

Additive manufacturing (AM) can be defined as a manufacturing process in which a component is built through the controlled addition of successive layers previously generated by the slicing of a 3D digital model of the part to be manufactured $[1,2]$. Within this context, the AM process is seen as an alternative to traditional subtractive manufacturing processes (SM) due to the possibility of manufacturing parts with complex geometries and, even so, with a high buy-to-fly ratio, benefiting sectors such as defense and aerospace $[2,3]$.

Another advantage of AM over SM is the ability to produce prototypes on a reduced time scale with lower costs, a feature that has already been harnessed for decades by the automotive industry, especially for polymeric parts. Currently, AM has also called the industry's attention to the manufacture of parts in metal alloys, focusing on more complex alloys based on titanium, nickel and aluminum, mainly because it saves material by producing the components in their net shape or near net shape [4]. The possibility of producing parts with composition or microstructure gradients and, consequently, gradual variations in their properties, known as Functionally Graded Materials (FGM), is also highlighted [5].

One of AM's technological variants for the construction of metal parts is called Directed Energy Deposition (DED). This categorization agglomerates the set of AM practices in which a thermal source is focused on the fusion of a feed material simultaneously with its deposition on a previously defined path, forming layers [6]. Within this category is the variant that combines an electric arc as thermal source and wire feeding, called Wire + Arc Additive Manufacturing (WAAM) which was addressed in this work.

Among the main advantages of the WAAM process is its high productivity compared to high intensity processes (laser and electron beam), being especially superior for the manufacture of parts with larger dimensions and volume $\left(>1000 \mathrm{~mm}^{3}\right)$ [7] and low dimensional complexity. Another positive factor is the possibility of using the same equipment of the already consolidated welding market, enabling the assembly of an operational setup with low capital investment. However, there are also challenges to be overcome, especially regarding the processability of materials. The main deleterious effects of the WAAM are the residual stresses formed in the built part as well as the anisotropy in the mechanical properties [7-9]. Currently, there is a lack of techniques aimed at mitigating these defects, and the most common solutions are focused mainly on variations in the strategy of deposition and control of the heat input [7].

A welding process that stands out for its superior controllability in heat input is the advanced variant of the GMAW process called Cold Metal Transfer (CMT). This process provides a more refined control over the melt pool. This is possible due to it short-circuit transfer mode with electric current control, concomitantly with the dynamic feed of the filler material in the form of wire. The high-frequency forward and reverse dynamics of the electrode wire facilitates the detachment of the metal drop at low electrical power. Thus, the surface tension between the molten drop at the tip of the wire and the molten pool becomes the main detachment force component $[10,11]$. Besides, there is also the possibility of using modes with greater energy such as the Pulse mode, characterized by current pulsation cycles, in which the metal transfer occurs in free flight, combined with cycles of $\mathrm{CMT}$, with short circuit transfers and regression of the wire.

The need for controlled thermal source power is justified due to the intrinsic WAAM layer by layer addition mode. During the deposition of successive layers, heat accumulates in the part being built. In this way, the variation of the physical properties of the molten pool is observed, such as its viscosity and surface tension, causing inconstancy in the geometry of each layer once they solidify with different cooling rates. The first layers, which solidify faster, have a larger height, while the successive warmer layers tend to solidify more widely. This behavior translates the importance of controlling the heat input to WAAM, a distinctive feature of the CMT process $[12,13]$. The reduction in the heat input favors the maintenance of a constant molten pool temperature during the construction of the part, avoiding large geometric variations between each layer. The evaluation of the thermal behavior with the acquisition of infrared videos during the process proved to be useful in optimizing the WAAM parameterization, allowing a better understanding of the thermal dynamics of the process, and therefore, this approach was used in this work [14-16].

Another way to keep the physical and dimensional properties of the molten pool constant is by controlling its temperature with cooling techniques. WAAM usually uses idle time between the deposition of subsequent layers. Typically, a fixed temperature is admitted interlayers, so the next layer only starts after the part reaches the desired cooling. Besides this passive form of thermal control, active forms of cooling are also studied, such as the construction of structures in an almost immersion environment [17] and the cooling by gas convection [18,19], however, these active techniques may turn the process more complex and costly, along with metallurgical issues.

The WAAM thermal behavior study is even more important for the construction of parts with large thicknesses in which the heat accumulation is greater compared to the thin structure. This work aims to evaluate the thermal dynamics in the construction of thick walls (width of $15 \mathrm{~mm}$ ) of 8 layers with the use of the CMT welding process. A comparison between two energy levels was proposed, using the short-circuit transfer mode (CMT-Conventional) and the mixed pulsed/short-circuit mode (CT-Pulse). The wall temperature during the deposition was measured by a thermographic camera. Different idle time were adopted between the deposition of each layer. The thermal cycles observed were compared between both process variants and different idle time. 


\section{Materials and Equipment}

The welding process used for the wall construction was the advanced variant of the GMAW process Cold Metal Transfer (CMT). The welding source model used was the CMT Advanced 4000R equipped with the RCU5000i configuration interface. An anthropomorphic Yaskawa Motoman HP20D robot was applied to displace the welding torch. Figure 1 illustrates the working cell, equipped with the Fronius welding source, the NX-10 controller, a rotating table and the Motoman HP20D robot, in addition to the usual peripherals for this type of procedure.

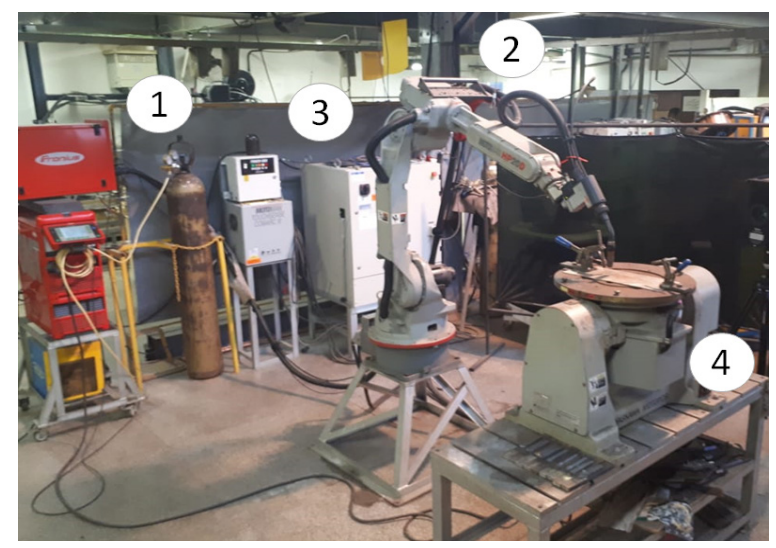

Figure 1. Working cell. (1) Welding Power Source Fronius CMT Advanced 4000R; (2) Robot Motoman HP20D; (3) Controller NX-10;

(4) Turn table.

For the capture of the thermal profile of the process during the wall manufacturing a FLIR SC7000 infrared thermographic camera was used. The camera operates in the spectral range from $7.7 \mu \mathrm{m}$ to $9.3 \mu \mathrm{m}$, and has video and image recording with a resolution of $320 \times 256$ with a pixel size of $29 \mu \mathrm{m}$. The distance from the camera to the region of interest was $1000 \mathrm{~mm}$ with an angle of $90^{\circ}$ to the specimen. The configuration adopted for the camera depends on optical physical variables such as an emissivity of 0.9 adopted according to the result of a calibration made with a thermocouple coupled to the infrared transducer.

The dimensions of the thick walls were defined with a length of $100 \mathrm{~mm}$ and width of $15 \mathrm{~mm}$, with the formation of eight layers with vertical increment of $2 \mathrm{~mm}$ from the first layer, resulting in a height of $18 \mathrm{~mm}$. Flat carbon steel SAE 1020 bars with dimensions of $150 \times 50 \times 12.7 \mathrm{~mm}^{3}$ were used as substrate for the construction of the walls. As filler metal it was used the stainless-steel alloy AWS ER309LSi of $1.0 \mathrm{~mm}$ with gas protection of $95 \% \mathrm{Ar}, 3 \% \mathrm{CO}_{2}$ and $2 \% \mathrm{~N}$.

\section{Experimental Methods}

The manufacturing parameterization began with the deposition of weld beads over flat sheets on the flat position. This preliminary step aimed to optimize the electrical and welding parameters in the CMT and Pulse modes in order to equalize the deposition rates while maintaining equal feed and welding speeds, as shown in Table 1. Thus, the geometry of the resulting deposit can be observed, mainly the reinforcement, using this measure to define the vertical increment ( $Z$ axis). Aiming to build thick walls of $15 \mathrm{~mm}$ width, the lateral material spreading technique known as weaving was applied, in which the welding torch follows an oscillating path simultaneously in the direction of the $\mathrm{X}$ and $\mathrm{Y}$ axes, as detailed in Figure 2.

Table 1. Electric and Welding Parameters.

$\begin{array}{cc}\text { CMT Pulse } & \text { CMT } \\ \text { Feeding speed (Va): } 4.5 \mathrm{~m} / \mathrm{min} & \text { Feeding speed (Va): } 4.5 \mathrm{~m} / \mathrm{min} \\ \text { Travel speed (Vs): } 15 \mathrm{~cm} / \mathrm{min} & \text { Travel speed (Vs): } 15 \mathrm{~cm} / \mathrm{min} \\ \text { Contact Tip to Work Distance (CTWD): } 15 \mathrm{~mm} & \text { CTWD: } 15 \mathrm{~mm} \\ \text { Pulse ratio/Short-circuit ratio: } 8: 1 & \text { Weaving frequency: } 1 \mathrm{~Hz} \\ \text { Weaving frequency (f): } 1 \mathrm{~Hz} & \text { Current (I): } 112 \mathrm{~A} \\ \text { Current (I): } 124 \mathrm{~A} & \text { Voltage (V): } 22 \mathrm{~V} \\ \text { Voltage (V): } 25 \mathrm{~V} & \text { Gas flow (Vg): } 20 \mathrm{I} / \mathrm{min} \\ \text { Gas flow (Vg): } 20 \mathrm{l} / \mathrm{min} & \text { "Z" increment: } 2 \mathrm{~mm}\end{array}$



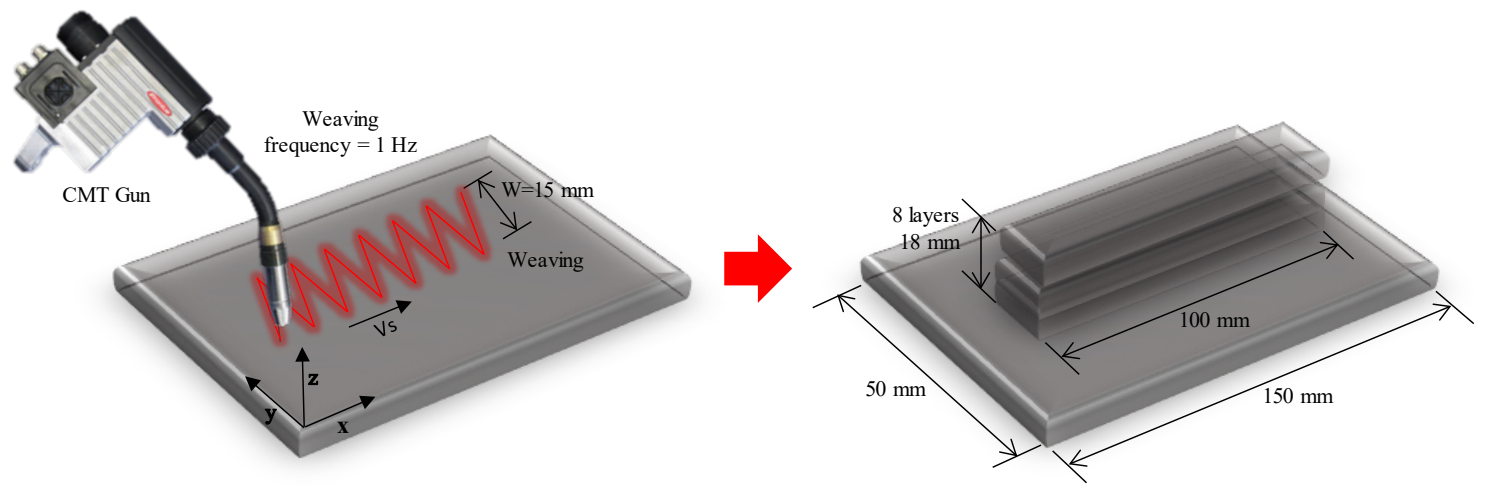

Figure 2. Schematic representation of lateral spreading triangular weaving technic and result after deposition of all layers, leading to a thick wall.

The interlayer idle times have been set to 0, 30, 60, 180 and 300 seconds. In order to acquire the thermal cycle during deposition, it was necessary to use two temperature ranges in the thermal camera. The first range (300 to $\left.1500{ }^{\circ} \mathrm{C}\right)$ was used to obtain the thermal behavior during the formation of the layers with a burning electric arc. The second range ( 0 to $300{ }^{\circ} \mathrm{C}$ ) was used to obtain the cooling data after arc extinction. For the purpose of thermal behavior analysis, a high temperature zone (HTZ) was defined, corresponding to temperatures above or equal to $900{ }^{\circ} \mathrm{C}$. A similar methodology was proposed by Bai et al. [15] and Chabot et al [16]. According to Bai et al. [15] choosing the emissivity value is still a hard task and the calibration is essential to minimize errors. A thermal couple was used to find the emissivity in this work.

With the analysis of the variation of the high temperature zone, corresponding to the variation of the heat accumulation in the part, one can compare the different interlayer idle time in this criterion. Aided by the thermal data treatment software Altair, the temperature values were measured as a function of the length of the layers as well as the time of deposition. Three temperature measurement regions were stipulated. They would consist of straight lines, two longitudinal to the layers and one transversal. Figure 3 illustrates the methodology used in the positioning of the points and acquisition lines to obtain the temperature data as well as the HTZ delimitation.

After the construction, cross sections of $20 \mathrm{~mm}$ width were sectioned from the central region of the walls for metallographic analysis. All the variables of process variant and interlayer idle time proposed in this work were able to build thick walls with dimensions near the expected, like exemplify the Figure 4. Once this paper aims to analyze the thermal aspects of $A M$, the dimensional values and deposit quality (like surface roughness) results will be presented in further work.

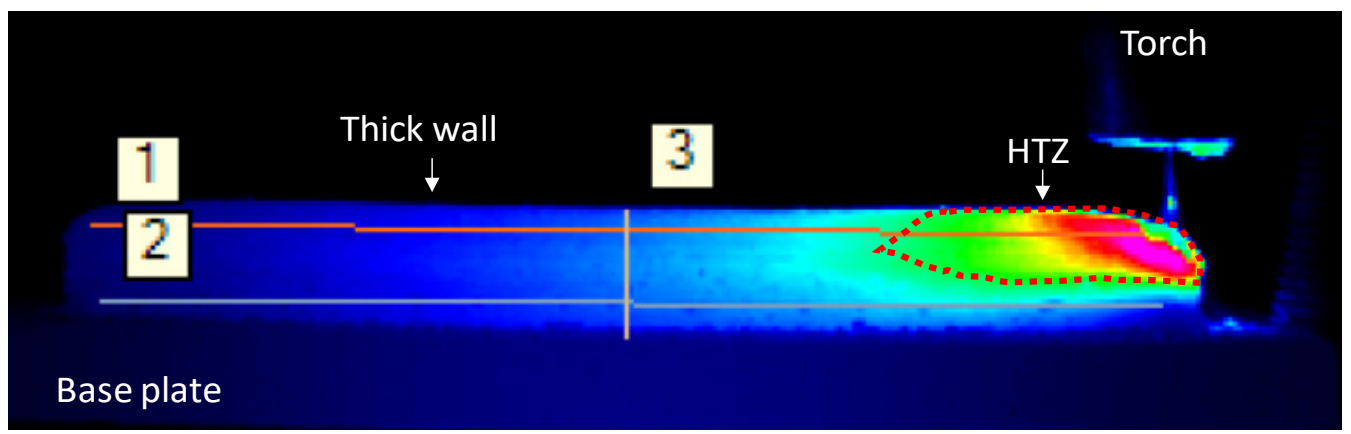

Figure 3. Thick wall lateral side view after finishing deposition of the last layer. Location of the three lines of temperature acquisition and indication of High Temperature Zone $(\mathrm{HTZ})\left(\mathrm{T}>900^{\circ} \mathrm{C}\right)$ by doted lines.

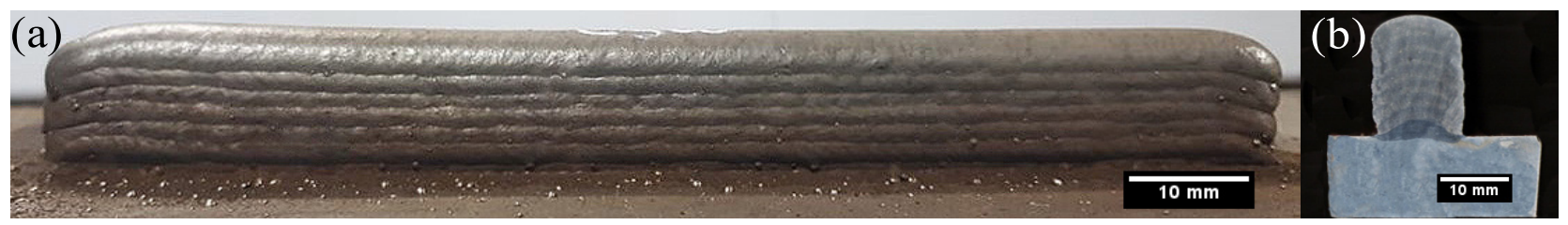

Figure 4. Additively manufactured thick wall made by CMT variant with 300 s interlayer idle time. (a) Lateral side view; (b) Cross section of the wall (middle of wall). 


\section{Results}

Figure 5 illustrates and compares the thermal profile of the two transfer modes with different interlayer idle time. The video frames of this figure refer to the instant immediately after the arc extinction, corresponding to the end of the deposit of the eighth and last layer. It is observed that as the interlayer idle time increases, the heat accumulation in the part decreases.

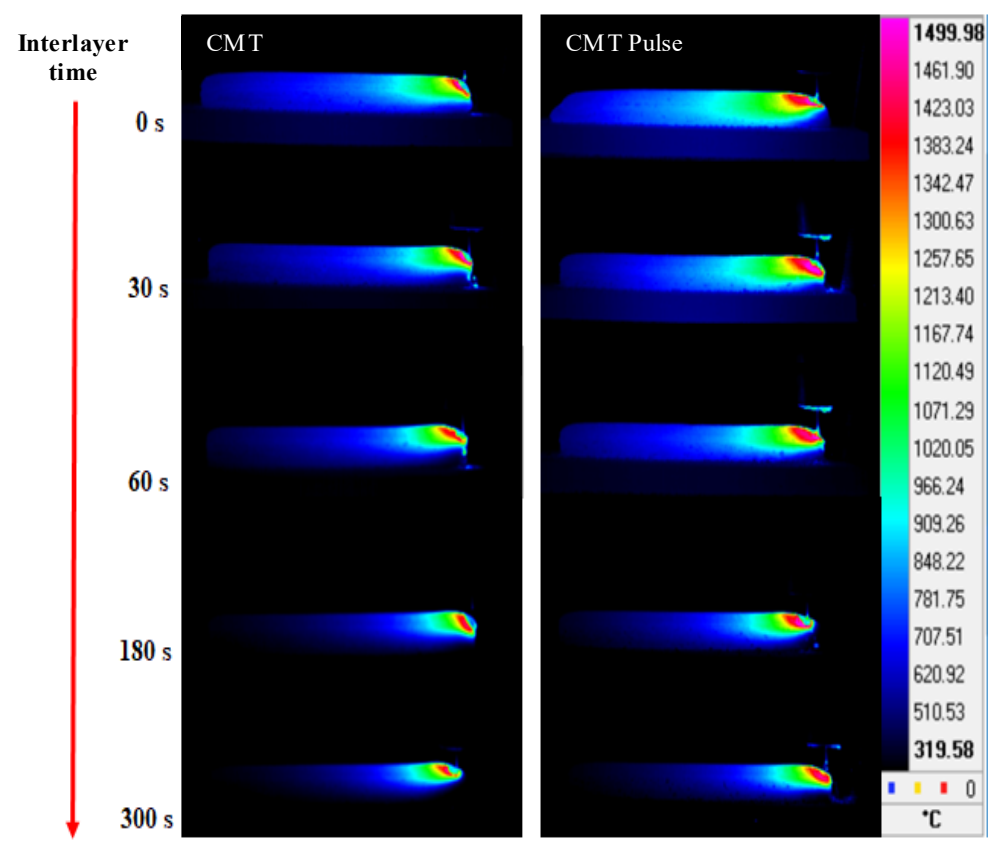

Figure 5. Temperature acquisition instantly after extinction of the electric arc in the eighth layer (last). The difference in thermal input of the CMT and CMT Pulse processes with different times between layers is evident.

To quantify the observed heat accumulation difference, the high temperature zone (HTZ) was measured for both process and interlayer idle time combinations, as shown in the graphs of Figure 6 . The measurements indicate the decreasing of the HTZ with the increase of interlayer idle time. Thus, it can be concluded that the increase of the interlayer idle time significantly influences the heat accumulation along the construction of the part. Figure 6 also illustrates the difference of thermal accumulation of the part between the two variants of the process, in which the CMT Pulse process presented higher HTZ, indicating higher thermal accumulation. As expected, the condition in which the greatest heat accumulation was observed for both cases was in the last layer without interlayer idle time $(0 \mathrm{~s})$, for which the Pulse variant yielded a HTZ $60 \%$ higher

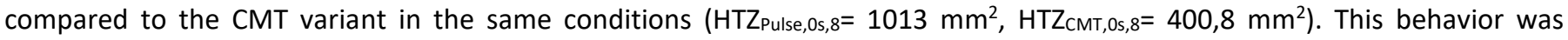
expected once the CMT Pulse mode, for the same wire feeding rate, inputs higher welding power than the short-circuit variant.

(a) $\mathrm{CMT}$

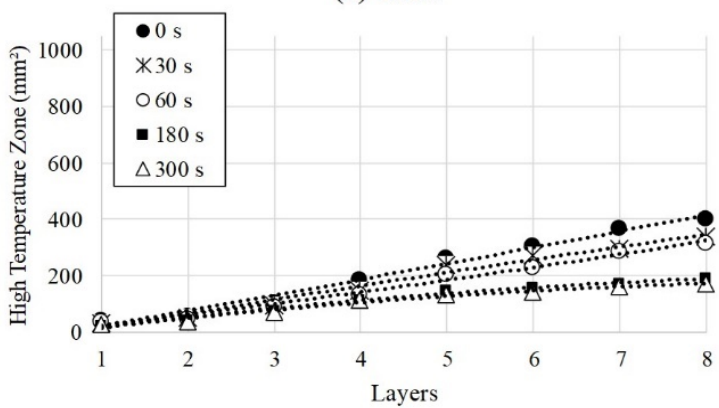

(b) CMT Pulse

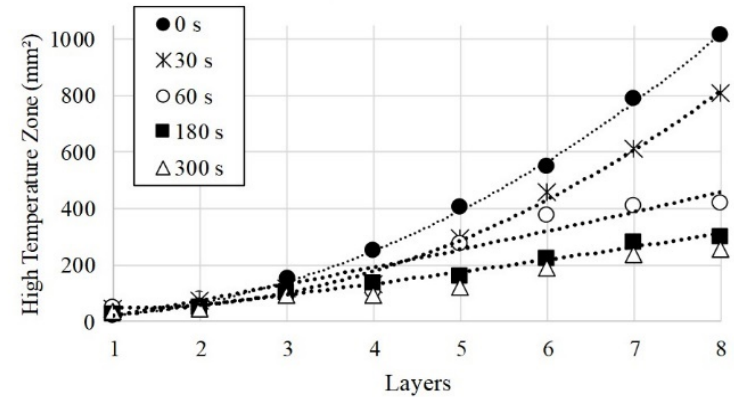

Figure 6. Comparison of the high temperature zone (above $900^{\circ} \mathrm{C}$ ) between each layer of (a) CMT process; and (b) CMT Pulse. 
Figure 6 shows that the heat accumulation in the specimen remained the same for both conditions until the third layer; only after the fourth layer there were significant variations in the HTZ. This difference was observed not only between the interlayer idle time, but also between the processes. It is observed that the same HTZ can be obtained with different process parameters by varying the interlayer idle time. In this way, this thermal control technique fits as a controller for layer dimensional aspects as well as for microstructural results.

To characterize the thermal behavior of the deposits, the average temperature between layers was measured. This measurement was performed according to the method of the medium lines mentioned above, measured at the moment before the striking of the electric arc. In other words, the interlayer idle time is awaited and then the temperature is measured. In the case of deposition without interlayer idle time, in which there is no arc extinction, the temperature was measured at the instant when the direction of the welding torch was reversed. Figure 7 shows the results.
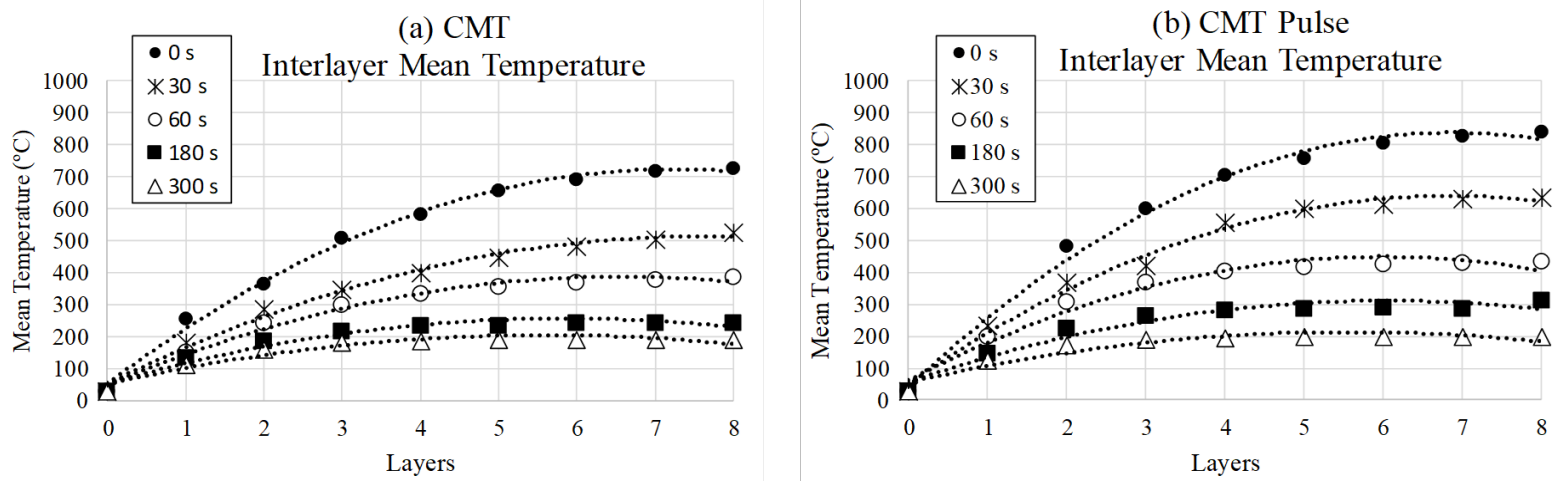

Figure 7. Temperature comparison between layers for each layer of (a) CMT; and (b) CMT Pulse.

Still in Figure 7, an increase of the temperature is observed, starting from the room temperature of $30{ }^{\circ} \mathrm{C}$, during the deposit of the successive layers. The shorter the interlayer idle time, the higher the average temperature between layers. In the comparison between the processes, the CMT Pulse variant presented on average interlayer mean temperature values $15.0 \%\left(64.4^{\circ} \mathrm{C}\right)$ higher. However, the longer the interlayer idle time, the smaller the difference, reaching an average of only $4.9 \%$ for the interlayer idle time of $300 \mathrm{~s}$ for the last layer. This demonstrates that, from a certain point between $300 \mathrm{~s}$ and $180 \mathrm{~s}$, for this welding energy, a plateau is reached in the heat exchange between the workpiece and the environment, and no appreciable advantages can be seen for applying different versions of the welding process (from the thermal standpoint). Figure 8 shows the global thermal cycles of wall deposition under all conditions. In these thermal cycles it is possible to observe the temperature peaks, referring to the deposition period, as well as the temperature valleys, referring to interlayer time. Even in the condition without interlayer idle time, it is possible to identify the change of direction of deposition, indicated by peaks and valleys. It is observed that the longer the interlayer idle time, the smaller the difference between the thermal cycle of the processes, showing that the thermal control contribution balance between the two thermal control methods assessed (interlayer idle time and welding process version) is not static, but varies with process (lesser extent) and with interlayer idle time (higher extent). 


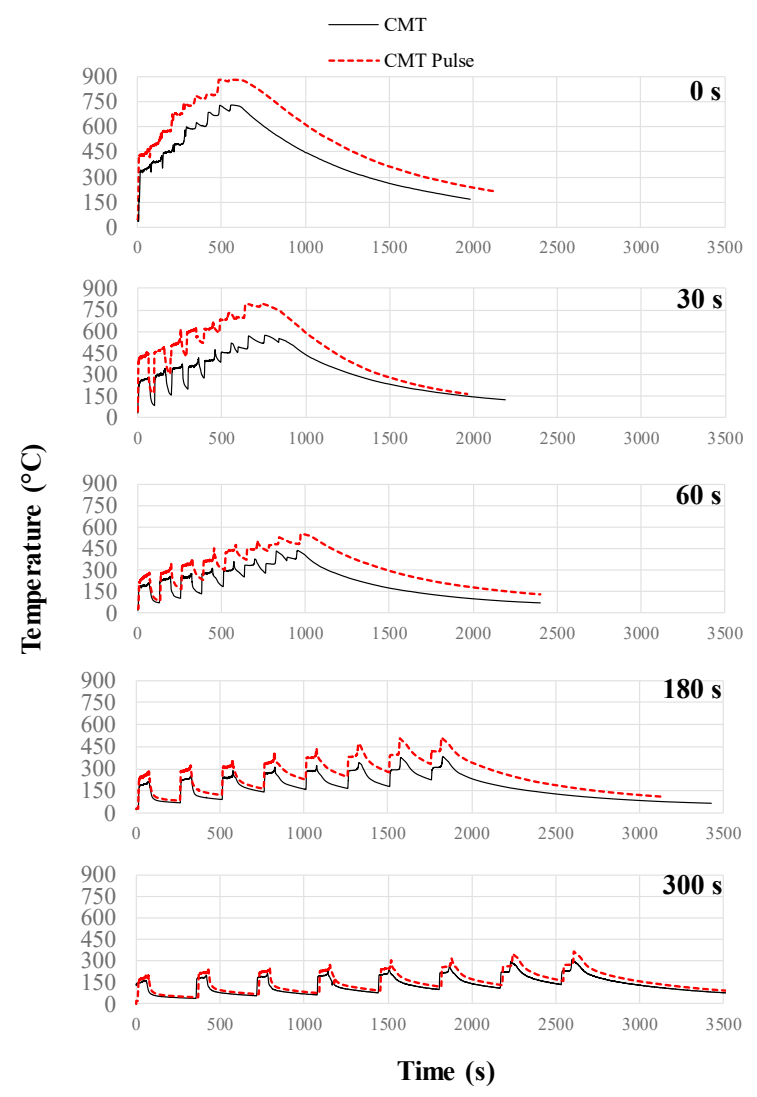

Figure 8. AM thermal cycle. Indicates the average temperature of the wall during deposition.

It is observed, in Figure 8, that the longer the interlayer time, the smaller the difference between the thermal cycle of the process's variants, indicating that the energy control contribution by means of interlayer time is effective. The CMT process variant peak temperature presented inferior values than for the CMT Pulse variant for all the interlayer idle time. The difference ranges from $17,09 \%\left(364.93{ }^{\circ} \mathrm{C}-306.66{ }^{\circ} \mathrm{C}=58.27{ }^{\circ} \mathrm{C}\right)$ for the 0 s interlayer idle time, to $15.97 \%$ $\left(879.75^{\circ} \mathrm{C}-729.37{ }^{\circ} \mathrm{C}=150.38^{\circ} \mathrm{C}\right.$ ) for the 300 s interlayer idle time.

\section{Conclusions}

The main conclusions of this study can be summarized in the following topics:

- According to the results of the tests performed, the possibility of using the two processes for additive manufacturing of thick walls was proven. However, the results indicated a high temperature zone (HTZ) up to $60 \%$ smaller for the CMT process, indicating a lower energy contribution necessary for the deposition of the same material feed rate. This energy difference is explained by the current pulsation cycles of the CMT Pulse process, which has a higher welding power/deposited material ratio;

- It is observed that the same HTZ can be obtained with different process - energy combinations by varying the interlayer idle time. In this way, this cooling technique could be used to control the layers dimension and further wall microstructure. However, further macro and microstructural analyses must be carried out to evaluate this assumption;

- According to the thermal cycles, it could be possible to control the thermal accumulation in the WAAM construction of thick walls by means of an open loop interlayer idle time temperature control system.

- The interlayer idle time significantly influences the entire construction time of the workpiece, thick walls without interlayer idle time were made in $9 \mathrm{~min}$, while with the maximum interlayer idle time of $300 \mathrm{~s} 42$ min were demanded. Therefore, the optimal interlayer idle time should be sought to reduce its impact on manufacturing time;

- The decision about the technology to be applied in terms of welding process version should also consider the fact that, beyond a given interlayer idle time, the influence of the process's thermal efficiency tends to become negligible. The importance of this conclusion lies on the fact that certain welding technologies incur higher costs (CAPEX, training, spare parts, etc.) than others. 


\section{References}

[1] Levy GN, Schindel R, Kruth JP. Rapid manufacturing and rapid tooling with layer manufacturing (Im) technologies, state of the art and future perspectives. CIRP Annals. 2003;52(2):589-609. http://dx.doi.org/10.1016/S0007-8506(07)60206-6.

[2] Alberti EA, Silva LJ, d’Oliveira ASCM. Manufatura aditiva: o papel da soldagem nesta janela de oportunidade. Soldagem e Inspeção. 2014;19(2):190-198. http://dx.doi.org/10.1590/0104-9224/SI1902.11.

[3] Ding D, Pan Z, Cuiuri D, Li H. A multi-bead overlapping model for robotic wire and arc additive manufacturing (WAAM). Robotics and Computer-integrated Manufacturing. 2015;31:101-110. http://dx.doi.org/10.1016/j.rcim.2014.08.008.

[4] Ding D, Pan Z, Cuiuri D, Li H. A practical path planning methodology for wire and arc additive manufacturing of thin-walled structures. Robotics and Computer-integrated Manufacturing. 2015;34:8-19. http://dx.doi.org/10.1016/j.rcim.2015.01.003.

[5] Bobbio LD, Otis RA, Borgonia JP, Dillon RP, Shapiro AA, Liu Z-K, et al. Additive manufacturing of a functionally graded material from Ti6Al-4V to Invar: experimental characterization and thermodynamic calculations. Acta Materialia. 2017;127:133-142. http://dx.doi.org/10.1016/j.actamat.2016.12.070.

[6] Ding D, Pan Z, Cuiuri D, Li H. Wire-feed additive manufacturing of metal components: technologies, developments and future interests. International Journal of Advanced Manufacturing Technology. 2015;81(1-4):465-481. http://dx.doi.org/10.1007/s00170-015-7077-3.

[7] American Society for Testing and Materials. ASTM F3187-16: standard guide for directed energy deposition of metals. 16th ed. West Conshohocken: ASTM; 2016. 22 p.

[8] Cunningham CR, Flynn JM, Shokrani A, Dhokia V, Newman ST. Invited review article: strategies and processes for high quality wire arc additive manufacturing. Additive Manufacturing. 2018;22:672-686. http://dx.doi.org/10.1016/j.addma.2018.06.020.

[9] Hu Z, Qin X, Shao T, Liu H. Understanding and overcoming of abnormity at start and end of the weld bead in additive manufacturing with GMAW. International Journal of Advanced Manufacturing Technology. 2018;95(5-8):2357-2368. http://dx.doi.org/10.1007/s00170017-1392-9.

[10] Selvi S, Vishvaksenan A, Rajasekar E. Cold metal transfer (CMT) technology: an overview. Defence Technology. 2018;14(1):28-44. http://dx.doi.org/10.1016/j.dt.2017.08.002.

[11] Dutra JC, Silva RHG, Savi BM, Marques C, Alarcon OE. Metallurgical characterization of the 5083H116 aluminum alloy welded with the cold metal transfer process and two different wire-electrodes (5183 and 5087). Welding in the World. 2015;59(6):797-807. http://dx.doi.org/10.1007/s40194-015-0253-0.

[12] Marques C. Prospecções da natureza física da soldagem Mig automática de ligas de alumínio [dissertação de mestrado]. Florianópolis: Universidade Federal de Santa Catarina; 2013.

[13] Rodriguez N, Vázquez L, Huarte I, Arruti E, Tabernero I, Alvarez P. Wire and arc additive manufacturing: a comparison between CMT and TopTIG processes applied to stainless steel. Welding in the World. 2018;62(5):1083-1096. http://dx.doi.org/10.1007/s40194-018-06066.

[14] Yang D, Wang G, Zhang G. Thermal analysis for single-pass multi-layer GMAW based additive manufacturing using infrared thermography. Journal of Materials Processing Technology. 2017;244:215-224. http://dx.doi.org/10.1016/j.jmatprotec.2017.01.024.

[15] Bai X, Zhang H, Wang G. Improving prediction accuracy of thermal analysis for weld-based additive manufacturing by calibrating input parameters using IR imaging. International Journal of Advanced Manufacturing Technology. 2013;69(5):1087-1095. http://dx.doi.org/10.1007/s00170-013-5102-y.

[16] Chabot A, Rauch M, Hascoët J-y. Towards a multi-sensor monitoring methodology for AM metallic processes. Welding in the World. 2019;63(3):759-769. http://dx.doi.org/10.1007/s40194-019-00705-4.

[17] Silva LJ, Souza DM, Araujo DB, Saad NS, Reis RP, Scotti A. Gerenciamento térmico via resfriamento ativo por quase-imersão aplicado à manufatura aditiva por fusão-deposição a arco. In: TMS 2017 146th Annual Meeting \& Exhibition Supplemental Proceedings; 2017; San Diego, CA. Pittsburgh: The Minerals, Metals \& Materials Society; 2017.

[18] Henckell P, Günther K, Ali Y, Bergmann JP, Scholz J, Forêt P. The influence of gas cooling in context of wire arc additive manufacturing: a novel strategy of affecting grain structure and size. In: TMS 2017 146th Annual Meeting \& Exhibition Supplemental Proceedings; 2017; San Diego, CA. Pittsburgh: The Minerals, Metals \& Materials Society; 2017.

[19] Wu B, Pan Z, Ding D, Cuiuri D, Li H, Fei Z. The effects of forced interpass cooling on the material properties of wire arc additively manufactured Ti6Al4V alloy. Journal of Materials Processing Technology. 2018;258:97-105. http://dx.doi.org/10.1016/j.jmatprotec.2018.03.024. 


\section{Erratum}

In the article "Analysis of Interlayer Idle Time as a Temperature Control Technique in Additive Manufacturing of Thick Walls by Means of CMT and CMT Pulse Welding Processes", DOI https://doi.org/10.1590/0104-9224/SI25.01, published in Soldagem \& Inspeção, vol. 25, pp. 01-08, on page 08:

Where it reads:

“[17] Silva LJ, Souza DM, Araujo DB, Saad NS, Reis RP, Scotti A. Gerenciamento térmico via resfriamento ativo por quaseimersão aplicado à manufatura aditiva por fusão-deposição a arco. In: TMS 2017 146th Annual Meeting \& Exhibition Supplemental Proceedings; 2017; San Diego, CA. Pittsburgh: The Minerals, Metals \& Materials Society; 2017."

It should be read:

"[17] Silva L, Felice I, Araujo D, Reis R, Scotti A. A novel active cooling technique for wire + arc additive manufacturing. In: Proceedings of the 25th International Congress of Mechanical Engineering; 2019; Uberlândia. Uberlândia: Universidade Federal de Uberlândia; 2019. http://dx.doi.org/10.26678/ABCM.COBEM2019.COB2019-1394." 